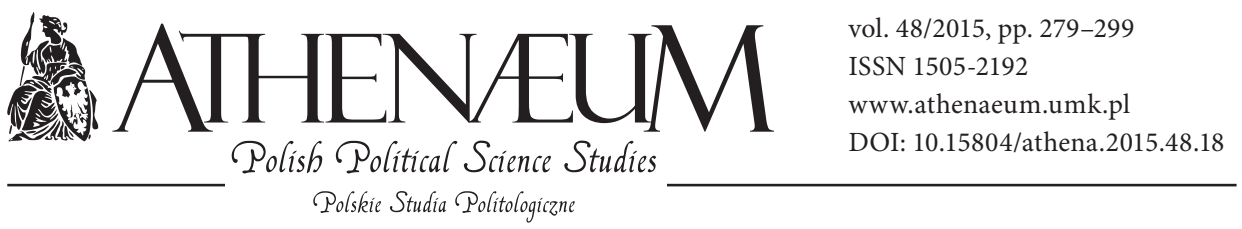

\title{
POLISH EUROSCEPTIC PARTIES IN THE LIGHT OF EP ELECTIONS. ANALYSIS OF THE EUROSCEPTIC "OPPORTUNITY STRUCTURE"
}

\author{
Aleksandra Moroska-Bonkiewicz*, \\ Joanna Kozierska**
}

\begin{abstract}
The objective of this article is to explain the differing levels of support achieved by Eurosceptic parties in European Parliament elections in Poland for the years 2004,2009, and 2014. Taking into account the specificity of EP elections, which in theory assign greater importance to European issues, the analysis is conducted using the "Eurosceptic opportunity structure", which is composed of: political space, social attitudes towards integration, and the external factor (the dynamics of the European integration process). Additionally, there is analysis of the attitudes of Eurosceptic parties standing for election. The analysis demonstrates that the supply and demand sides created a similar opportunity structure for Eurosceptic parties in all three elections, while the external factor provided those parties with greater possibilities in 2004 and 2014. Analysis of the attitudes of Eurosceptic parties, however, indicated that they had greater chances to attract voters by invoking the European question in 2004 and 2014. The combination of these conclusions along with the support received by Eurosceptics in particular elections confirms the validity and the explanatory function of the adopted assumptions, while emphasizing the fundamental role played by the parties themselves in the examined aspect. Nonetheless, to confirm the primary
\end{abstract}

* University of Lower Silesia, Department of Security and International Affairs.

** University of Wrocław, Institute of Political Science. 
assumption and state with more certainty the impact of the European issue on electoral behaviours, more in-depth analysis is necessary.

\section{- KEYWORDS}

European Parliament elections, parties' positions, Euroscepticism, Euroenthusiasm, opportunity structure, electoral support

\section{INTRODUCTION}

European elections are increasingly attracting the attention of scholars from a range of disciplines. One sure reason is the fact that support is systematically growing for Eurosceptic groups, who have turned the European Parliament elections into a forum for voicing their objections to the process of European integration, among other issues.

According to the academic literature, the successes of the Eurosceptic parties are very often explained with the theory of the "second order" character of European elections (Reif, Schmitt 1980, Reif 1984, Marsh 1998). Such elections, which are not decisive for the exercise of political power at the national level, may be viewed by the electorate as an opportunity to express discontent with the current government, or with (mainstream) parties more generally, and thus encourage voters to look beyond the traditionally dominant parties. As such, these contests are frequently marked by the emergence or success of smaller protest parties, often with distinctive agendas. What is more, the higher profile given to European issues by EP elections further tends to make these elections particularly attractive arenas for expressing discontent with European politics, generating votes for political movements focused on European integration, particularly Eurosceptic parties (Harmsen, Spiering 2004: 23).

The objective of the research is thus to explain the performance of Eurosceptic parties in the EP elections in Poland. This is an interesting case to study, as over the previous three elections support for Eurosceptic parties has fluctuated significantly. In 2004, Eurosceptics recorded their highest level of support at $28.54 \%$; in 2009, that support fell to $4.19 \%$, while in the most recent elections in 2014 , Eurosceptic groups were the beneficiaries of $15.69 \%$ of votes ${ }^{1}$.

1 The research was co-financed by funds from the University of Lower Silesia Faculty of Social Sciences and Journalism in 2014 as part of a research project. 
Considering the specificity of elections to the EP, which in theory give higher profile to European issues, in our analysis we assigned the most importance to European issues analysed through the lenses of the "Eurosceptic opportunity structure" and the activity of Eurosceptic parties in this respect. We assume that this approach can be helpful in explaining the electoral performance of Eurosceptic parties. We are also aware that this is not the only explanation. European Parliament elections are difficult to separate from their social and political context in the country, as well as the specificities of particular parties and their electorate. Nevertheless, the perspective adopted in this article will primarily highlight the European question.

The research is based on a qualitative analysis of the electoral manifestoes and materials presented by parties: flyers, electoral spots, and statements by leaders during election campaigns ${ }^{2}$. When source materials were not available, we reviewed secondary sources in the form of reports and analyses. To define the demand side, we have used public opinion polls conducted mainly by CBOS (Public Opinion Research Centre).

\section{THEORETICAL BACKGROUND}

The concept "Eurosceptic opportunity structure" is based on the theoretical structure of supply and demand analysis applied most frequently in explaining the success of populist and radical right parties (see Mudde 2007). For this reason, when examining the supply side we draw attention to the nature of the rivalry focused on European issues within the party system, analysing if a "political opportunity structure" on the issue of Europe exists. Kitschelt argues that in order for such an opportunity structure to develop, the mainstream parties need to cluster around the centre, leading to the creation of an opening in the political spectrum. Convergence of mainstream parties around a socially important issue may lead to the appearance of niches in the political space, meaning a gap can open up between the distribution of electoral preferences and the positions adopted by political parties (Kitschelt, McGann 1995). In this situation, the "specific arena dimension theory" (Hainsworth, O’Brien, Mitchell 2004: 53) tells us that a party offering a different and clear agenda in a given issue can benefit

\footnotetext{
2 A significant portion of the analyzed materials comes from the Workshop for Documentation and Studies on Political Life at the University of Wrocław, Institute of Political Science (PDiBŻP).
} 
from the absence of differences between the agendas of the other parties, and also when the other parties present ambivalent, poorly-defined agendas. This theory is also reflected in the "issue voting theory" by A. Campbell (1960) in the aspect of the issue position of a party (Falter, Schoen 2005: 228-229).

On the demand side, the analysis will cover the social perception of the European integration process. Of importance is whether there is a differentiation among the attitudes of public opinion towards integration, and whether society demonstrates Eurosceptic tendencies. However, it should be emphasized that research on the demand side indicating the potential electorate of such parties does not provide an answer to the question of why certain voters cast their votes, nor how many potential voters will vote for them. The answer to this question would require statistical analysis of the electorates of particular parties, which exceeds the remit of this article.

These factors should be mentioned alongside the contextual aspects. In respect of the European elections, we place particular emphasis on external determinants, which may be associated with the dynamics of the European integration process. These factors can influence shifts in the positions of parties towards European integration. They can also impact social perception of the integration process. They create conditions for parties which are capable of exploiting the changing conditions for rapidly mobilizing electoral support by taking advantage of the European issue (Milner 2000; Benedetto, MoxonBrowne, Quaglia 2004; Moroska 2010).

Thus, our central argument is that a combination of the political space available, the electoral potential and the contextual environment can create more or less favourable Eurosceptic opportunity structure in Poland. At the same time, we concur with Mudde that "irrespective of how favourable the breeding ground and the political opportunity structure might be to political parties, they merely present political actors with a series of possibilities. In the end, it is still up to the parties to profit from them" (2007: 256). For this reason, it is also necessary to engage in an in-depth analysis of the attitudes assumed by Eurosceptic parties: what was their exact position on integration (according to their programs and electoral rhetoric), was it coherent and cohesive, was it distinct from that of mainstream parties. Among others, these are the factors which, according to the theory of issue voting, can contribute to casting a vote for a given party (Falter, Schoen 2005: 228-229).

The research is based on the concept of Euroscepticism proposed by Professors Taggart and Szczerbiak, which defines hard and soft Euroscepticism. 
However, the concept has been modified and broadened, ultimately constructing a four-item classification of positions on European integration.

Supporters of European integration

Opponents of European integration

\begin{tabular}{|c|c|c|c|}
\hline \multicolumn{2}{|c|}{ Euroenthusiasm } & \multicolumn{2}{c|}{ Euroscepticism } \\
\hline hard & soft & soft & hard \\
\hline
\end{tabular}

Fig. 1. Positions on European integration

Source: Moroska 2010: 69.

Crucial for this concept is the division between Euroenthusiasm and Euroscepticism, which is based on the idea of the status quo. Eurosceptics accept at most the current state of European integration (status quo). Euroenthusiasts agree to the further, planned development of the integration process. Both attitudes can present different levels of intensity in more moderate (soft) and radical (hard) positions. Hard Euroscepticism is a principled opposition to the integration project based on the transfer of state competences/power to supranational institutions. It can demand an exit from the European Union and/or build an alternative project which is much more narrow in comparison to the present $\mathrm{EU}$, or reduction of the competencies of the EU to the situation as it stood before the present treaties, such as under the regime of the Maastricht treaty. Soft Eurosceptics express a definite opposition to the further development of the integration process, enlargement of the EU's institutional competencies, and construction of a federal Europe. In the case of the candidate countries, they do not oppose membership but they are also not enthusiastic about it; the attitude is unclear and uncertain. Euroenthusiast positions could be described by analogy. Soft Euroenthusiasts are in favour of further integration but at a moderate tempo and to a limited extent. They can question some elements of the integration process and competencies of the EU, but they are not critical of further development of the whole process. In the case of candidate countries, membership could be conditional. Hard Euroenthusiasts fully accept the prospect of further European integration (transfer of state competencies to the supranational level). This can manifest itself in the postulate of strengthening the EU institutions and the support for the federal Europe (Moroska 2010: 68-72). It should be kept in mind that in practice, the borders between particular ideal types are significantly less clear. In many cases, the elements of particular types blend together in the programmes of political parties. 


\section{POLISH ATTITUDES TOWARDS EUROPEAN INTEGRATION (DEMAND SIDE ANALYSIS)}

Public opinion polls show that support in Poland for the country's accession to the European Union in the period from the inception of democratic transformation up to the day preceding the accession referendum in 2003 oscillated between $55 \%$ and $77 \%$; those opposed amounted to $6 \%$ in 1994 and over $30 \%$ in 2003 (CBOS: BS/119/100/95, BS/137/2000, BS/182/2003). The highest level of support for integration was achieved by the accession referendum held on June $7-8^{\text {th }}$, 2003 , which recorded $77.45 \%$ of votes in favour and $22.55 \%$ opposed $^{3}$.

A visible but temporary drop in support for the idea of European integration immediately following the accession referendum in the period between November 2003 and April 2004 should be noted. During this time, supporters of integration constituted $60 \%-64 \%$ of those surveyed, while opponents were $29 \%-30 \%$. This reduction in support immediately following Poland's entrance into the EU was the result, among others, of significant social uncertainty regarding the "new reality" posed by a united Europe.

Just before the first elections to the EP, in May 2004 support for integration rose slightly (to $71 \%$ ), while the percentage of those opposed fell to $20 \%$. In the following years, support for the idea of integration grew continually, achieving a level of $89 \%$ in the run-up to elections in 2014. The proportion of opponents of integration fell to $7 \%$ in 2014 (Cichocki 2011). Since 2004, only once there has been a significant collapse in support among Poles for integration. It occurred at the turn of 2012 and 2013, and in December 2013 reached a record low of $72 \%$ (opposed - 21\%). Such low support was explained as being mainly determined by the crisis in the Euro zone and the resultant economic slowdown in Poland (CBOS: BS/196/2004, BS/64/2009, BS/56/2014).

Despite the high level of support for Polish membership in the EU, particularly in the years 2005-2014 Poles were not equally supportive of all attempts to further "deepen" European integration.

In 2004, this was shown in attitudes towards the Treaty on a Constitution for Europe, and in 2009 towards the Lisbon Treaty. In both cases, the number of opponents reached nearly $20 \%$. Additionally, in 2009, $21 \%$ of Poles felt that the integration process had gone too far, while in 2014 the percentage of people polled expressing this opinion rose to 29\%. Moreover, in the period 2004-2014,

\footnotetext{
3 Turnout for the referendum was $58.85 \%$.
} 
there was a significant increase in reluctance towards the European Monetary Union and the common currency. In 2004 and 2009, around 38\% of Poles were against adoption of the Euro, while in 2014 this number grew to $72 \%$ (TNS Pentor; CBOS 151/2014).

While Poles do perceive many benefits flowing from Poland's membership in the EU (the most salient are the opening of borders, the possibility of finding work outside the country, the influx of European funds including co-financing of road infrastructure investments), an opening was available to Eurosceptic parties in the form of pointing out the negative influences that survey respondents felt were generated by integration with the European Union. Opinion polls indicated such factors as limitations on Poland's sovereignty, the subordination of the country to decisions taken by the EU authorities and the lack of equality among Member States as, in the opinion of respondents, the most important decisions are taken by the largest and richest states (CBOS 54/2014).

In summary, it should be stated that while a significant majority of Poles demonstrate a pro-EU attitude, the opposition of a portion of society to significant aspects of integration, as well as the specific nature of EP elections ("second order elections") which provide voters with the chance to follow their "hearts" rather than "heads" (voters have no need to vote strategically in fear of their vote being rendered meaningless as there is 'less at stake' than in more important "first order elections") (Reif, Schmitt 1980; Reif 1984), create electoral opportunities for Eurosceptic parties.

\section{PARTY POSITIONS ON EUROPEAN INTEGRATION IN EP ELECTIONS (POLITICAL SPACE ANALYSIS)}

Before proceeding to supply side analysis, it is necessary to give an overview of the electoral committees which took part in the election and the support they received, indicating their position towards European integration (see Tab. 1). Generally speaking, the Polish political space, in contrast to many western European countries such as Germany and the Netherlands, is characterized by a lesser degree of convergence of mainstream political parties around European issues. Since 2001 (the moment when the groups currently dominant on the Polish political scene came to the fore), the party system has hosted a full spectrum of attitudes, from Euroenthusiastic to parties at the edge of Euroenthusiasm and Euroscepticism, to hard Eurosceptics. Similarly to the attitudes of society at large 
towards integration, the majority of Polish political parties were characterized by an unequivocal Euroenthusiastic position on European integration. Their support was relatively stable, oscillating between $52 \%$ and $69 \%$ during particular elections (see Tab. 1). On the other extreme, support for devoutly Eurosceptic groups was characterized by significant fluctuations, polling between $4.19 \%$ and $29 \%$ in particular EP elections. A unique aspect of the Polish political scene is the relatively high support (19\% in 2004 and 32\% in 2014) for groups which can be regarded as straddling the border between soft Euroenthusiasm and soft Euroscepticism. The strong groups of this type, support for which demonstrates a growth trend, are doubtlessly important from the perspective of the electoral strategy adopted by the two groups of parties described above.

It should be emphasized that the division into Euroenthusiasts and Eurosceptics is not clearly linked with the left-right ideological divide. Nevertheless, among Eurosceptic groups the dominant formations are right-wing, frequently displaying populist and extremist tendencies. The Euroenthusiastic scene is dominated by centrist and left-wing groups.

Tab. 1. Political committees and their support in EP elections ${ }^{4}$

\begin{tabular}{|c|c|c|c|}
\hline $\begin{array}{l}\text { Election } \\
\text { year and } \\
\text { aggregate } \\
\text { support }\end{array}$ & $\begin{array}{l}\text { 'Eurosceptic' } \\
\text { Committees }\end{array}$ & $\begin{array}{l}\text { 'Border' } \\
\text { Committees }\end{array}$ & $\begin{array}{l}\text { 'Euroenthusiast' } \\
\text { Committees }\end{array}$ \\
\hline 2004 & $\begin{array}{l}\text { - League of Polish Families } \\
\text { (LPR) - 15,92\% } \\
\text { - Self-Defense of the } \\
\text { Republic of Poland (SRP) } \\
\text { - 10,78\% } \\
\text { - The Union of Real Politics } \\
\text { (UPR) - 1,87\% } \\
\text { - All-Poland Citizen Com- } \\
\text { mittee (OKO) - 0,58\% }\end{array}$ & $\begin{array}{l}\text { - Law and Justice (PiS) } \\
\text { - } 12,67 \% \\
\text { - Polish Peasants' Party } \\
\text { (PSL) - 6,34\% }\end{array}$ & $\begin{array}{l}\text { - Civic Platform (PO) - 24,1\% } \\
\text { - Democratic Left Alliance - } \\
\text { Labor Union (SLD-UP) - 9,35\% } \\
\text { - Freedom Union (UW) - 7,33\% } \\
\text { - Social Democracy of the Repu- } \\
\text { blic of Poland (SDPL) - 9,35\% } \\
\text { - National Electoral Committee } \\
\text { (NKWW) - 1,56\% } \\
\text { - National Party of Retirees and } \\
\text { Pensioners - People's Democra- } \\
\text { tic Party (KPEiR-PLD) - 1,56\% } \\
\text { - Initiative for Poland (IdP) } \\
\text { - 1,45\% } \\
\text { - Polish Labour Party (PPP) } \\
\text { - 0,54\% }\end{array}$ \\
\hline & $28,54 \%$ & $19,01 \%$ & 52,45 \\
\hline
\end{tabular}

${ }^{4}$ Only nationwide committees. 


\begin{tabular}{|c|c|c|c|}
\hline $\begin{array}{l}\text { Election } \\
\text { year and } \\
\text { aggregate } \\
\text { support }\end{array}$ & $\begin{array}{l}\text { 'Eurosceptic' } \\
\text { Committees }\end{array}$ & $\begin{array}{l}\text { 'Border' } \\
\text { Committees }\end{array}$ & $\begin{array}{l}\text { 'Euroenthusiast' } \\
\text { Committees }\end{array}$ \\
\hline \multirow[t]{2}{*}{2009} & $\begin{array}{l}\text { Republican Right (PR) } \\
-1,95 \% \\
\text { Libertas (LP) - 1,14\% } \\
\text { The Union of Real Politics } \\
\text { (UPR) }-1,1 \%\end{array}$ & $\begin{array}{l}\text { Law and Justice (PiS) } \\
-27,4 \%\end{array}$ & $\begin{array}{l}\text { Civic Platform (PO) - 44,43\% } \\
\text { Democratic Left Alliance - Labor } \\
\text { Union (SLD-UP) - 12,34\% } \\
\text { Polish Peasants' Party (PSL) } \\
-7,01 \% \\
\text { Agreement for the Future (PdP) } \\
-2,44 \% \\
\text { Self-Defense of the Republic of } \\
\text { Poland (SRP) - 1,46\% } \\
\text { Polish Labour Party (PPP) - 0,7\% }\end{array}$ \\
\hline & $4,19 \%$ & $27,04 \%$ & $68,77 \%$ \\
\hline 2014 & $\begin{array}{l}\text { Solidary Poland (SP) } \\
-3,98 \% \\
\text { Poland Together (PR) } \\
-3,3 \% \\
\text { The Congress of the New } \\
\text { Right }(\mathrm{KnP})-7,15 \% \\
\text { National Movement (RN) } \\
-1,4 \%\end{array}$ & $\begin{array}{l}\text { Law and Justice (PiS) } \\
-31,78 \%\end{array}$ & $\begin{array}{l}\text { Civic Platform (PO) - 32,13\% } \\
\text { Democratic Left Alliance - Labor } \\
\text { Union (SLD-UP) - 9,44\% } \\
\text { Polish Peasants' Party (PSL) } \\
-6,8 \% \\
\text { Europa Plus - Your Movement } \\
\text { (EP-TR) - 3,58\% }\end{array}$ \\
\hline & $15,69 \%$ & $31,78 \%$ & $52,53 \%$ \\
\hline
\end{tabular}

Source: Państwowa Komisja Wyborcza (National Electoral Commission).

\section{Euroenthusiast and "border parties" position}

An essentially unchanged hard Euroenthusiastic position is maintained by post-communist left-wing groups (Democratic Left Alliance - SLD, frequently forming election lists together with Labor Union - UP), as well as its splinter group (Social Democracy of the Republic of Poland - SDPL), the post-Solidarity liberal Freedom Union (UW), and the liberal Your Movement (TR) ${ }^{5}$. They have supported both Poland's rapid entry into the EU and then a deeper process of integration, going as far as a federal Europe model (Zuba 2009; Eurowybory 2009 2010) (see Fig. 2, 3, 4).

\footnotetext{
5 Previously known as the Movement of Support (2010) and Palikot's Movement (2011-2013).
} 
The liberal-right Civic Platform (PO), one of the dominant parties on the Polish political scene, falls during the analysed period (2004-2014) between hard and soft Euroenthusiasm, slightly adjusting its attitude based on its position on the government-opposition axis, as well as the adopted election strategy (see Fig. 2, 3, 4). The party presented an essentially positive attitude towards further integration, expansion of the EU's authority and strengthening of community institutions at a moderate pace; nevertheless, in 2004, it conditioned acceptance of the Constitutional Treaty on retention of Poland's voting power established under the Nice Treaty. After the elections of 2005, the party quickly withdrew from the "Nice or death"6 stance, shifting towards hard Euroenthusiasm (Zuba 2009). Since that time, it has consistently emphasized that Poland's place is inside European structures, while simultaneously proposing measures to strengthen them by presenting moderately pro-federal attitudes. The party has unequivocally supported the introduction of the Euro in Poland, but has yet to specify when this would take place (Eurowybory 2009 2010; Spots 2009 \& 2014).

The conservative Law and Justice (PiS) party, which is the second-largest party on the Polish political scene, as well as the smaller Polish People's Party (PSL) (particularly in elections of 2004), have presented largely ambivalent attitudes towards European integration, which straddle the border between soft Euroenthusiasm and soft Euroscepticism. The parties have supported a loose international model based on the concept of a "Europe of Nations". Both membership in the EU and further integration, including adoption of the Constitutional Treaty, were conditioned on their being in the Polish national interest (Moroska 2010). The dualistic attitude of Law and Justice towards European integration was the result of a division in that respect among the party's members and its electorate. By adopting the 'border' position, the party tried to maintain internal cohesion as well as to capture both the sceptical and the mildly Euroenthusiastic electorate. By the same token its position became the largest challenge for Eurosceptic parties. In the period being discussed (2004-2014), the position of Law and Justice on the European issue was moving slightly to one of the mentioned directions, depending on their current strategy and position (in opposition or in government). Nonetheless, it is difficult to identify radical differences in the party's attitude in the period leading up to European elections. The only noticeable change occurred between the 2004 and 2009 elections when Law and Justice shifted slightly towards soft Euroenthusiasm, yet it

\footnotetext{
6 The Civic Platform slogan to retain Nice Voting System in the European Constitution.
} 
did not abandon its radical criticism of integration and the EU itself, aiming at attracting the Eurosceptic electorate. In 2014, while PiS did express its opposition to the federalization of Europe, the party did not exclude deeper integration, including Poland's accession to the Eurozone, but on condition that such was clearly beneficial to the Polish national interest (Eurowybory 2009 2010; Prawo i Sprawiedliwość 2014).

After 2005, PSL slightly changed its attitude towards European integration, adopting a moderate pro-European stance; surprisingly, Self Defense (SRP) did the same, abandoning its criticism of European integration and the EU, taking similar positions to PSL (see Fig. 2, 3, 4) (Zuba 2009).

Smaller Euroenthusiastic parties appeared during particular elections, such as NKWW and KPEiR-PLD in 2004, and PdP in 2009, as well as the previously mentioned TR in 2014. They were not, however, a permanent feature of the political scene. An exception is the Polish Labour Party (PPP), participants in two elections (2004 and 2009), adopting a soft Euroenthusiastic position in both (Eurowybory 2009 2010).

The preceding analysis indicates that the distance between mainstream parties on the issue of European integration converged in 2009. In addition, the positions of these parties should be considered more Euroenthusiastic than in the 2004 elections. This situation was sustained in the 2014 elections. In accordance with theory, this creates more favourable conditions for Eurosceptic parties. Nonetheless, the position of Law and Justice underwent only a minor shift, which, in the context of the political space, did not significantly change the situation of Eurosceptic parties in the three analysed elections. The Eurosceptic parties thus had access to an open space for hard Eurosceptic positions, yet they were forced to compete with Law and Justice for the more moderate Eurosceptic electorate.

Analysis of the demand and supply side (opening in the political spectrum) demonstrates that the "Eurosceptic opportunity structure" was similar in all three elections, while in 2014 it seems slightly more favourable considering the larger percentage of Eurosceptic attitudes among the society. In this situation, and in accordance with Mudde, who argues that it is still up to the parties to profit from the political opportunity structure, it is necessary to analyse the Eurosceptic part of the political scene. 


\section{Eurosceptic parties' positions}

As in the case of the mainstream parties, the positions of Eurosceptic parties are diverse in terms of the strength of their attitudes, arguments invoked, and clarity of electoral offer. They also took place in quite diverse circumstances, taking into consideration mainly European context.

Elections to the European Parliament in 2004 were primarily symbolic, as they were the first held in Poland following its accession to the European Union. In addition, the week following the elections was to feature the signing of a new treaty establishing a Constitution for Europe. Nevertheless, the campaign was dominated by national issues rather than European ones. The discussion concerning the Constitutional Treaty, as well as that of the conditions imposed on Poland to join the EU and the apprehensions associated with them, were reflected in the campaign to a very limited degree. The discussion primarily concerned the political and economic crises Poland was experiencing at that moment (Szczerbiak 2004; Spots 2004). The only party that tried to take full advantage of the European issue was the League of Polish Families (LPR). The party adopted a clear and hard Eurosceptic position, which not only opposed further integration and the Constitutional Treaty, but also demanded an in/out referendum for Poland's EU membership, as well as restriction of the integration process to purely economic cooperation in the form of the European Economic Community (see Fig. 2). This party was distinguished from other Eurosceptic groups by its radically nationalist and Catholic anti-EU rhetoric, which portrayed the EU as threat to the Polish sovereignty and Christian values (Eurowybory 2004 2005; Moroska, Zuba 2010). The second largest Eurosceptic party, Self Defence (SRP), emphasized that it was in favour of Poland's integration with the European Union, but under the principles of a Europe of Nations, equal rights and legal, political and economic equality. This meant that Self Defence was opposed to the federalizing trend in Europe, limitations on national sovereignty and the conditions of Poland's accession to the EU. In respect of that last aspect, it focused primarily on issues associated with the economy and demanded renegotiation of the accession treaty, particularly its agriculture and industry terms (Eurowybory 2004 2005; Stanowisko Samoobrony 2005; Spots 2004). In general, SRP presented a rather ambivalent attitude towards European integration, somewhere between hard and soft Euroscepticism. A characteristic shared by both analysed parties was populism, which manifested itself in such aspects as close coupling of antiEU rhetoric with criticism and aversion towards Polish political elites who, in 
those parties' view, worked to serve foreign interests, leading to the collapse of the state. They made themselves out to be the sole defenders of the true national interest (Eurowybory 2004 2005; Moroska 2010: 245-251). The All-Poland Citizen Committee (OKO), formed just before the elections, expressed its protest in similar terms. However, its position towards the EU was unclear. In its programme and election flyers the committee made only brief mention of the need to renegotiate the terms of association with the EU, simultaneously expressing support for the development of European states within the EU on the basis of equality and maintenance of sovereignty, with respect for cultures and religions (Eurowybory 2004 2005; Spots 2004). The Union of Real Politics (UPR), however, presented a clear "soft" stance towards European integration (see Fig. 2). It came out in support of membership while remaining opposed to the current direction of integration heading towards a supranational and federal structure. It proposed retention of the universal consensus voting standard, limiting the power of the EU authorities and reducing the EU bureaucracy (Eurowybory 2004 2005; Spots 2004). In comparison to SRP, and particularly LPR, UPR criticised integration and the EU in far less radical terms, placing itself closer to the position of Law and Justice (see Fig. 2).

The situation in Poland and Europe changed dramatically in 2009. After the stormy coalition government of PiS-SRP-LPR that led to the ultimate disappear-

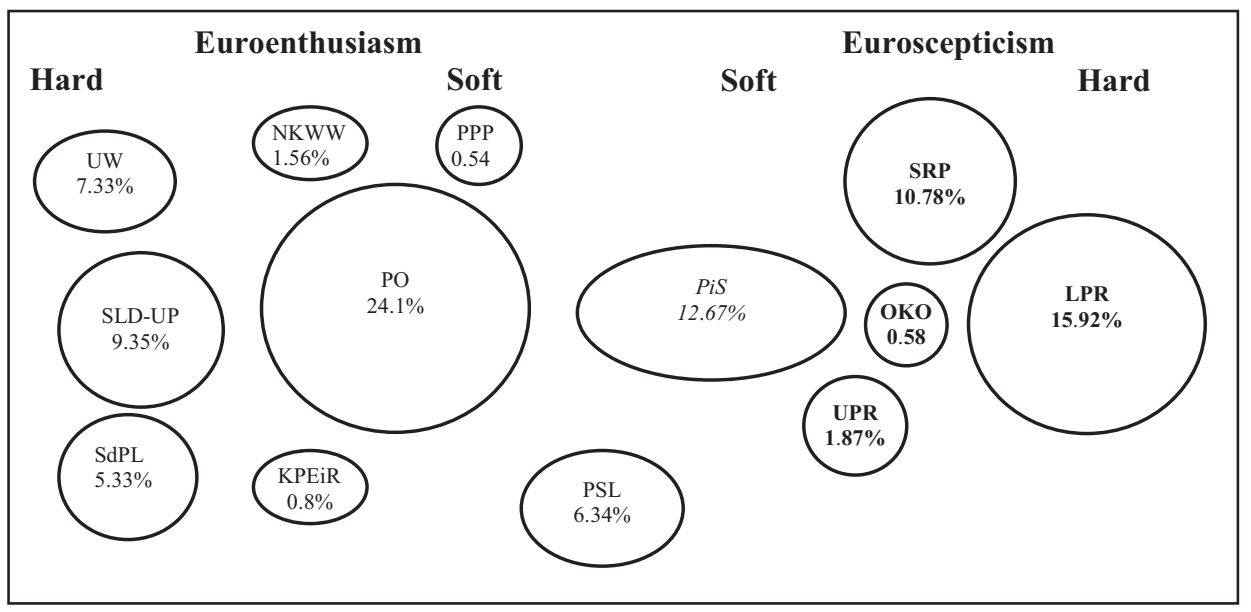

Fig. 2. Polish political parties' attitudes toward the EU, 2004 election Source: Authors' illustration. 
ance of the two smaller coalition partners from the domestic political scene, Civic Platform and the Polish People's Party assumed power, leading to stabilization of the country's political situation. At the same time, Poland was perceived as a "green island" floating among a sea of European states drowning in economic crisis. Both these factors doubtlessly strengthened the country's position in the European Union. After the failure to ratify the Constitutional Treaty, the EU managed to prepare an abridged version of the pact to reform the European Union in the form of the Lisbon Treaty. Elections to the European Parliament were held after the Lisbon Treaty, following the difficult process of ratification in 2008, had received the blessing of the largest political parties (ratified by the Polish Parliament in April 2008) and only awaited the President's signature (Szczerbiak 2009; Zuba 2010). Thus, during the election campaign, it did not give rise to any particularly strong emotions. As was the case in 2004, the 2009 campaign was dominated by domestic issues, the main theme of which was the country's economic condition (among others the impact of the crisis on Poland's economy was discussed). The discourse was monopolized by two blocks - the governing Civic Platform and opposition Law and Justice, which clearly sought to marginalize smaller parties (Spots 2009; Eurowybory 2009 2010). Europe was not absent from the campaign, but the mainstream parties battled over who would best represent Poland's interests in the EU. Only Eurosceptic groups - the Union of Real Politics, the Polish branch of Libertas, and the Republican Right (PR) - made efforts to address this issue, dedicating significant time to it in election spots, programmes and flyers (Szczerbiak 2009; Eurowybory 2009 2010; Spots 2009).

The Eurosceptic parties generally presented more moderate stances compared to 2004 (see Fig. 3). All accepted Poland's membership in the EU and the conditions of Poland's accession while at the same time expressing their strong objection to further integration in the form of the Lisbon Treaty. UPR, as in the previous campaign, invoked the idea of a Europe of Nations, opposing further integration, the common currency and the EU bureaucracy. Similar postulates, draped in less radical clothes, were voiced by PR. Both parties in their anti-EU rhetoric made visible reference to ideological elements such as the threat to Christian values and Polish identity, as well as protection of national sovereignty; however, this was similar to the conservative-patriotic rhetoric of Law and Justice, which in 2009 strongly emphasized the emotional aspect, pointing to the threat to national interests coming primarily from Germany (Eurowybory 2009 2010; Spots 2009). 
Two important aspects of the 2009 elections must be highlighted. First, the ambiguous attitude to European integration presented by Libertas, the party founded by the Irish millionaire Declan Ganley a few months before election. Ganley himself did not want to be labelled a "Eurosceptic", criticising the EU and opposing the Lisbon Treaty mostly for its anti-democratic character. The starkly Eurosceptical position of the Polish politicians in Libertas (former League of Polish Families politicians) contradicted Ganley's seemingly pro-European declarations. The contradiction was deepened by placing several pro-European politicians on the Polish Libertas election slate. Such a strategy deepened the illegibility of the formation's profile; the strategy was vague and dubious. It left the party vulnerable to attacks by other Eurosceptic groups and from PiS (Zuba 2010: 87-89). Second, none of the Eurosceptic groups participating in the 2009 elections could be considered protest groups. While primarily Libertas and, to a degree, UPR voiced criticism of the elite in Brussels, on the domestic plane those parties did not represent themselves as protest parties. This was particularly emphasized by the Republican Right party, which declared on the first page of its election manifesto that "We are not a party of protest, but rather a party seeking to fix Polish politics" (Eurowybory 2009 2010: 138).

In 2014, the EU experienced what was likely the most serious internal crisis in its history, which over time had an increasingly negative impact on European

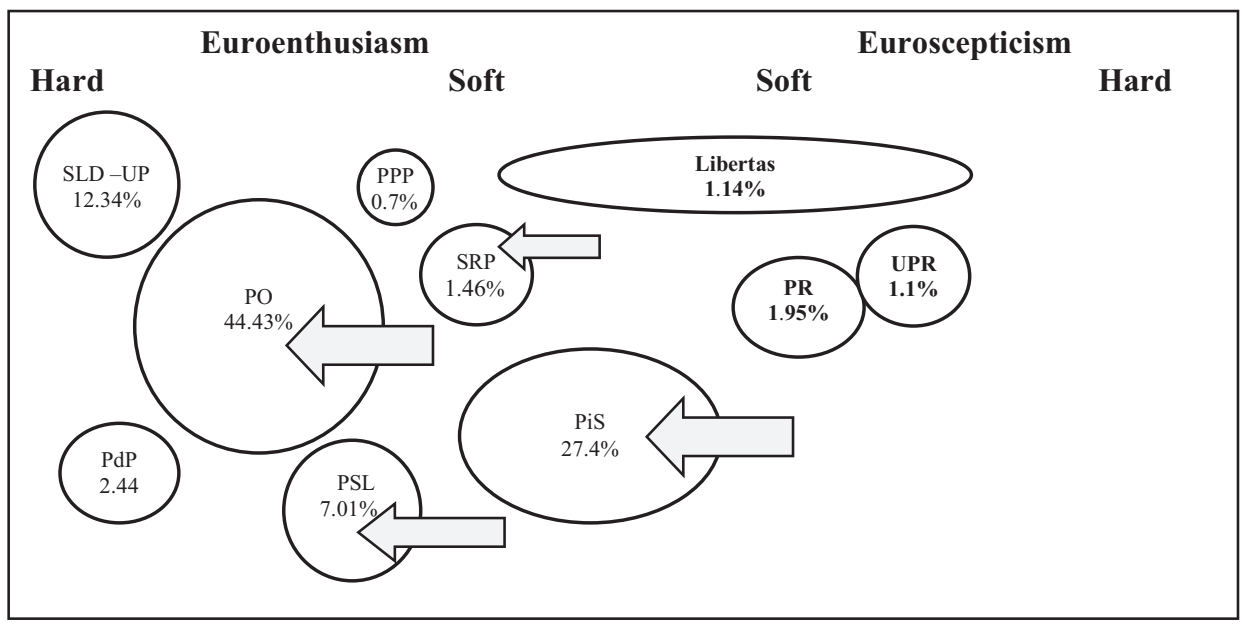

Fig. 3. Polish political parties' attitudes toward the EU, 2009 election Source: Authors' illustration. 
society. The fiscal and economic problems that beset the Eurozone affected not only the 17 countries that had adopted the common currency, but also the other Member States to varying degrees. At the same time, internal divisions among EU states crystallized, such as between rich and poor states, and those inside and outside the Eurozone. The economic crisis, excessive bureaucracy and slow decision making equally weakened the EU's international position. This gave a boost to Euroscepticism across Europe. In the United Kingdom, the UK Independence Party (UKIP) came out on top, while in France the victors were the National Front (FN). Eurosceptics also achieved electoral success in Denmark, Greece, Austria, the Netherlands, Italy, and Hungary. In Poland, Eurosceptic parties also increased their support, particularly in comparison to 2009 .

In 2014, similarly to 10 years earlier, a greater radicalization of anti-EU attitudes and thus polarization between the Eurosceptic parties and Law and Justice occurred (see Fig. 4). As previously mentioned, PiS expressed opposition to the idea of a federal Europe, but did not exclude the idea of deeper integration to the extent that such would bring clear benefits to Poland. The Eurosceptic parties took the opposite position, not perceiving any advantages at the political level to integration. Three of the four Eurosceptic parties - Solidary Poland, New Right Congress, and the National Movement - demanded not only the halting of European integration, opposing the Lisbon Treaty, but also restriction of the integration process to purely economic cooperation (Solidarna Polska 2014; Kongres Nowej Prawicy 2014; Ruch Narodowy 2014; Spots 2014). The New Right Congress, and particularly its leader, Janusz Korwin-Mikke, went so far as to demand the rolling-up of the EU. Only Poland Together expressed opposition to further integration in a more measured tone (Polska Razem 2014).

In the election programmes and campaigns of the Eurosceptics, the EU was depicted primarily as a threat to Polish national interests, particularly in respect of the economy and values. The Polish economy was supposedly under threat mainly by the forcing of new climate and energy regulations, European rules governing shale gas extraction and limitations on coal mining. This last issue was of particular importance in light of the domestic situation, as miners employed strikes and protests in the months leading to the election to voice their displeasure with government policy. The issue of Polish agriculture was also touched on, stating the necessity of improving payments to farmers. However, taking into account the scale of the crisis gripping the EU, it is quite curious that the Eurosceptics made in fact no efforts at politicizing this issue. The parties placed far more emphasis on axiological issues rather than economic ones, 
appealing to the Christian values which Eurosceptics claimed were under threat by the EU law being imposed on Poland. Solidary Poland, Poland Together, and the National Movement, but also Law and Justice claimed that Polish national identity, traditions, culture, customs and way of life should be protected at all costs from the tendencies demonstrated at the EU level to conduct "dangerous cultural experiments" (Solidarna Polska 2014; Kongres Nowej Prawicy 2014; Ruch Narodowy 2014; Prawo i Sprawiedliwość 2014; Spots 2014).

Because the election campaign was largely focused on domestic themes, in the main on criticism of the ruling parties (PO and PSL from 2007 on), Eurosceptics attempted to use their outsider position by making the campaign a protest against mainstream parties. This opposition was also joined to the European issue, with declarations such as the statement that Poland is poorly represented by the elite in the European arena. Criticism of Prime Minister Donald Tusk was expressed by all parties, such as Poland Together, who stated that his activities posed a direct threat to Polish Christian values. Solidary Poland attacked not only the ruling Civic Platform party, but also Jarosław Kaczyński as the leader of Law and Justice, emphasizing that both he and PM Tusk had failed Poland by their actions on the European scene, and had therefore ceased to be trustworthy in the eyes of Poles.

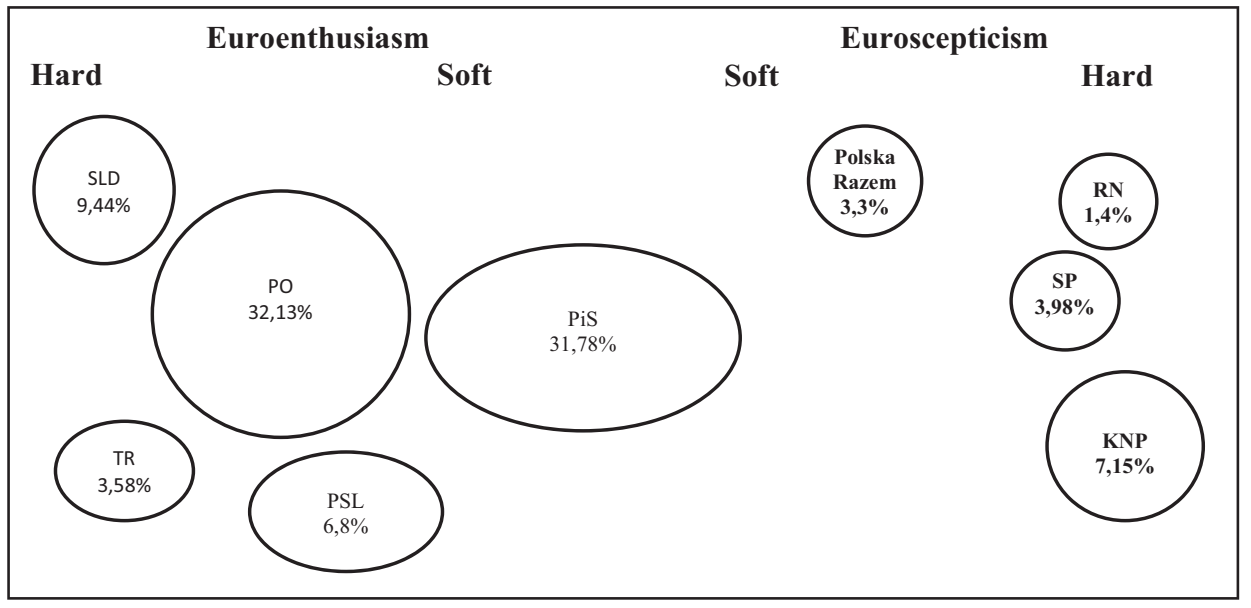

Fig. 4. Polish political parties' attitudes toward the EU, 2014 election Source: Authors' illustration. 
The preceding analysis has demonstrated that a characteristic of Eurosceptics' positions and rhetoric in 2004 and 2014 was not only greater radicalism in their attitudes, but also sharp criticism of domestic political elites, who were perceived as working against the national interest within the EU. These elements were far less visible in the 2009 campaign.

\section{CONCLUSIONS}

The objective of the preceding analysis was to explain the performance of Eurosceptic parties in the EP elections in Poland in 2004, 2009, and 2014, by assigning the most importance to European issues analysed through the "Eurosceptic opportunity structure" and the activity of Eurosceptic parties in this respect. We assumed that a combination of the political space available, the Eurosceptic potential among society, the contextual environment (particularly the dynamic of the European integration process) can create a more or less favourable "structure" for Eurosceptic parties. At the same time, we also assume that the attitudes and behaviours of the Eurosceptic parties themselves constitute an important factor, as they have the potential to make greater or lesser use of the opportunities that arise.

The analysis has demonstrated firstly that, in spite of a generally high level of support for European integration among Polish society, in all of the analysed elections there were visible negative attitudes towards various aspects of the integration process, creating potential opportunities for Eurosceptic parties. Secondly, analysis of the supply side (opening in the political spectrum) demonstrates that the political space for Eurosceptic parties was similar in all three elections. Thirdly, in respect of contextual factors, and particularly external ones, it would seem that the dynamic of the European integration process and events associated with it were more favourable to Eurosceptic parties in 2004 and 2014 than in 2009. Fourthly, and what would seem of greatest significance, in the 2004 and 2014 elections (differently from the 2009 elections) Eurosceptic parties demonstrated strong decentralizing tendencies in adopting hard Eurosceptic attitudes. By the same token, they differentiated to a significantly greater extent than in 2009 in respect of their electoral offering in comparison to the closest party on the Eurosceptic-Euroenthusiast axis: Law and Justice. They, therefore, created a situation in which their appeal could be distinguishable for the voters. Moreover, particularly in the context of the "second order elections" theory, 
the clear protest by Eurosceptics in the 2004 and 2014 campaigns could have contributed more to their achievements at the polls than in 2009.

To summarize, in accordance with the adopted theoretical assumptions, the analysis has demonstrated that Eurosceptic parties had greater chances to attract the Eurosceptic electorate in 2004 and 2014 than in 2009. These conclusions along with the support garnered by the Eurosceptics in individual elections has confirmed the credibility of the adopted assumptions and its explanatory function in respect of the electoral performance of Eurosceptic parties, while indicating the fundamental role of the parties themselves in the aspect under study. Nevertheless, in order to confirm the primary findings and more confidently ascertain the impact of the European issue on the voting behaviour, it must be subjected to further in-depth analysis regarding inter alia voters' awareness of the European question, as well as of differences in the positions taken by political parties and whether the European question was important for the electorate of the parties being studied (Falter, Schoen 2005: 228-229). These aspects take on particular importance considering the fact that in all of the analysed elections, the campaign was focused on internal issues while only marginally addressing European integration.

\section{REFERENCES:}

Benedetto G., Moxon-Browne E., Quaglia L. (2004). Euroscepticism among West European Communist Parties in France, Spain and Italy: A Comparative Analysis. IPSA Annual Conference. Lincoln: University of Lincoln.

CBOS. Research Reports. [online] http://www.cbos.pl/PL/publikacje/raporty.php; [accessed 21.06.2014].

Cichocki P. (2011). Polish Attitudes Towards the European Union. „Przegląd Zachodni" 3.

Eurobarometr 72. Opinia publiczna w Unii Europejskiej. Raport krajowy Polska. [online] http://ec.europa.eu/public_opinion/archives/eb_arch_en.html; [accessed 21.06.2014].

Eurowybory 2004. Kandydaci i programy. (2005). I. Słodkowska, M. Dołbakowska (eds.). Warszawa: Wydawnictwo Instytut Studiów Politycznych PAN.

Eurowybory 2009. Kandydaci i programy. (2010). I. Słodkowska, M. Dołbakowska (eds.). Warszawa: Wydawnictwo Instytut Studiów Politycznych PAN.

Hainsworth P., O’Brien C., Mitchell P. (2004). Defending the Nation: The Politics of Euroscepticism on the French Right. [in:] Euroscepticism: Party Politics, National Identity and European Integration. R. Harmsen, M. Spiering (eds.). "European Studies" 20. 
Handbuch Wahlforschung. (2005). J.W. Falter, H. Schoen (eds.). Wiesbaden: VS Verlag.

Harmsen R., Spiering M. (2004). Introduction: Euroscepticism and the Evolution of European Political Debate. [in:] Euroscepticism: Party Politics, National Identity and European Integration. R. Harmsen, M. Spiering (eds.). "European Studies" 20.

Hix S., Marsh M. (2011). Second-Order Effects Plus Pan-European Political Swings: An Analysis of European Parliament Elections across Time. "Electoral Studies" 30 (1).

Kitschelt H., McGann A.J. (1995). The Radical Right in Western Europe: A Comparative Analysis. Ann Arbor: University of Michigan Press.

Kongres Nowej Prawicy (2014). Program Kongresu Nowej Prawicy na Unio-wybory 2014. [online] http://www.nowaprawicajkm.pl; [accessed 26.06.2015].

Marsh M. (1998). Testing the Second-Order Election Model after Four European Elections. "British Journal of Political Science" 28 (4).

Milner S. (2000). Introduction: A Healthy Scepticism?. "Journal of European Integration" 1.

Moroska A. (2010). Prawicowy populizm a eurosceptycyzm (na przykładzie Listy Pima Fortuyna w Holandii i Ligi Polskich Rodzin w Polsce). Wrocław: Wydawnictwo Uniwersytetu Wrocławskiego.

Moroska A., Zuba, K. (2010). Two Faces of Polish Populism. The Causes of the Success and Fall of Self Defense and the League of Polish Families. "Totalitarismus und Demokratie" 7.

Mudde C. (2007). Populist Radical Right Parties in Europe. Cambridge: Cambridge University Press.

Polska Razem (2014). Wielka Polska w małej Unii - program europejski Polski Razem. [online] http://polskarazem.pl; [accessed 26.06.2015].

Prawo i Sprawiedliwość (2014). Program Prawa i Sprawiedliwości 2014. [online] http:// www.pis.org.pl; [accessed 26.06.2015].

Reif K. (1984). National Election Cycles and European Elections, 1979 and 1984."Electoral Studies" 3.

Reif K. (1985). Ten Second-Order National Elections. [in:] K. Reif (ed.), Ten European Elections. Aldershot: Gower.

Reif K., Schmitt H. (1980). Nine Second-Order National Elections. A Conceptual Framework for the Analysis of European Election Results. "European Journal for Political Research" 8.

Ruch Narodowy (2014). Postulaty programowe Ruchu Narodowego z II Kongresu RN 3 Maja 2014. [online] http://narodowcy2014.pl; [accessed 26.06.2015].

Solidarna Polska (2014). Europejski Dekalog Solidarnej Polski. [online] http://www. solidarna.org.pl; [accessed 26.06.2015].

Spots. (2004). Election Spots Issued on TVP1, TVP 2 and the Regional TV Dolny Śląsk, from the Period of the 2004 Election Campaign.

Spots. (2009). Election Spots Issued on TVP1, TVP 2 and the Regional TV Dolny Śląsk, from the Period of the 2009 Election Campaign. 
Spots. (2014). Election Spots Issued on TVP1, TVP 2 and the Regional TV Dolny Śląsk, from the Period of the 2014 Election Campaign.

Stanowisko Samoobrony. (2005). Stanowisko Samoobrony Rzeczypospolitej Polskiej wobec odrzucenia przez Francje Traktatu Konstytucyjnego. [online] http://www. samoobrona.org.pl/pages/02.Partia/03.Stanowska/indexphp?document=942.html; [accessed 26.06.2007].

State Election Commission Database. (2014). [online] www.pkw.gov.pl; [accessed 21.06.2014].

Szczerbiak A. (2004). The European Parliament Election in Poland, 13 June 2004. "European Parliament Election Briefing" 1. [online] https://www.sussex.ac.uk/webteam/gateway/file.php?name=epern-no-1-poland-2004.pdf\&site $=266$; [accessed 26.06.2007].

Szczerbiak A. (2007). Why do Poles Love the EU and What Do They Love About It?: Polish Attitudes Towards European Integration During the First Three Years of EU Membership. SEI Working Paper, No. 98.

Szczerbiak A. (2009). The European Parliament Election in Poland, 7 June 2009. "European Parliament Election Briefing” 36. [online] https://www.sussex.ac.uk/webteam/ gateway/file.php?name=epern-no-36-poland-2009.pdf\&site=266; [accessed 26.06.2010].

TNS Pentor. Eurobatalia. [online] http://pentor-arch.tnsglobal.pl/53936.xml?doc_ id=11278; [accessed 20.04.2015].

Zuba K. (2009). Through the Looping Glass: The Attitudes of Polish Political Parties towards the EU Before and After the Accession. "Perspectives on European Politics and Society" 3.

Zuba K. (2010). Polskie Partie Eurosceptyczne w wyborach do parlamentu Europejskiego w 2009 roku. „Athenaeum. Polskie Studia Politologiczne” 23. 